\title{
Field Response of Glyphosate-Tolerant Soybean to Herbicides and Sudden Death Syndrome
}

\author{
S. Sanogo, X. B. Yang, and P. Lundeen, Department of Plant Pathology, Iowa State University, Ames 50011
}

\begin{abstract}
Sanogo, S., Yang, X. B., and Lundeen, P. 2001. Field response of glyphosate-tolerant soybean to herbicides and sudden death syndrome. Plant Dis. 85:773-779.

Three-year field experiments were conducted to assess the development of sudden death syndrome (caused by Fusarium solani f. sp. glycines) in three soybean cultivars, tolerant (P9344 and A3071) and nontolerant (BSR101), to glyphosate following foliar application of four herbicides (acifluorfen, glyphosate, imazethapyr, and lactofen) commonly applied to soybeans in the north-central region of the United States. Cultivar A3071 is resistant to sudden death syndrome, whereas cultivars P9344 and BSR101 are susceptible to this disease. There was no statistically significant cultivar-herbicide interaction with respect to the severity of foliar symptoms of the disease and the frequency of isolation of $F$. solani f. sp. glycines from roots of soybean plants. Across all herbicide treatments, the level of sudden death syndrome was lower in the diseaseresistant cultivar than in the susceptible ones. There was an increase in the disease levels under application of acifluorfen, glyphosate, and imazethapyr compared with nontreated or lactofentreated plants. The results obtained indicate that the response of glyphosate-tolerant soybeans to sudden death syndrome is not different from the response of conventional soybeans to this disease following application of the selected herbicides, and the resistance of soybean to sudden death syndrome was not changed with application of glyphosate.
\end{abstract}

A purpose of genetically modified crop cultivars is to provide new, efficient methods of crop management to control weeds, insects, and plant pathogens $(8,10,12,33)$. Soybean growers are rapidly embracing the use of herbicide-tolerant cultivars, especially cultivars tolerant to the herbicide glyphosate. In 1998, 38\% (approximately 11 million hectares) of U.S. soybean acreage was planted to transgenic soybeans, with approximately 8 million hectares planted to glyphosate-tolerant soybeans alone (20). With the adoption of herbicidetolerant crops, herbicide usage is rapidly changing. In 1995, a year before glyphosate-tolerant soybean cultivars were first grown commercially, imazethapyr, trifluralin, pendimethalin, glyphosate, thifensulfuron, chlorimuron, and bentazon were the most widely used herbicides in soybean in Iowa, and were applied to 76 , $30.3,27.9,19.9,18.6,10.4$, and $10.3 \%$ of soybean acreage, respectively (17). In 1999 , the percentage of soybean acreage treated with imazethapyr declined to $29 \%$, whereas soybean acreage treated with glyphosate increased to $58 \%$ (3).

Production systems based on the use of herbicide-tolerant soybeans, such as glyphosate-tolerant, again raise questions

Corresponding author: X. B. Yang
E-mail: xbyang@iastate.edu

Accepted for publication 2 April 2001.

Publication no. D-2001-0514-02R

(C) 2001 The American Phytopathological Society about herbicide effects on plant pathogens. Over the past four decades, numerous studies have been conducted on many facets of the biology and ecology of plant pathogens in relation to herbicides applied to various crops, including soybean. The side effects of herbicides on plant diseases are quite variable; incidence and severity of some tions, whereas they decreased with other diseases $(1,2)$. In fact, increased plant resistance to some diseases was recorded following the application of certain herbicides that induce plant-mediated responses involved in disease suppression $(7,43)$. There is little information on the interaction of herbicide-tolerant crop cultivars with plant pathogens after application of herbicides, and the available information emanates from controlled-environment studies $(26,38)$.

This study examines the development of sudden death syndrome of soybean, caused by the soilborne fungus Fusarium solani $\mathrm{f}$. sp. glycines (34-36), in glyphosate-tolerant soybean under field conditions. Sudden death syndrome of soybean is a disease of increasing economic importance in the United States (35). Concerns from farmers and trade journals about increased levels of this disease in glyphosate-tolerant soybeans (38) prompted the undertaking of this study. There are no previous reports on the effect of herbicides, including glyphosate, on sudden death syndrome in soybean and its causal agent under field conditions. Although little is known about how the use of glyphosate in glyphosatetolerant soybean will impact diseases diseases increased with herbicide applica-
$(26,38)$, in non-glyphosate-tolerant crops this herbicide has been shown to increase populations of various fungal pathogens in soil $(9,27,29,42)$ and to suppress plant defenses and enhance disease susceptibility in various crops and weeds $(5,19,21,22$, $24,25,30,40,45)$.

The goal of this study was to assess the field response of glyphosate-tolerant and conventional soybeans to sudden death syndrome following application of selected herbicides commonly used in soybean in the north-central region of the United States.

\section{MATERIALS AND METHODS}

Herbicides and cultivars. Four herbicides were tested in this study: acifluorfen (Blazer), glyphosate (Roundup Ultra), imazethapyr (Pursuit 2AS), and lactofen (Cobra 2EC). The recommended field application rates $(1 \times)$ used for each formulated herbicide were $0.41,0.22,0.071$, and $0.84 \mathrm{~kg}$ a.i./ha for acifluorfen, lactofen, imazethapyr, and glyphosate, respectively. Three soybean cultivars were used in this study: Pioneer 9344 (hereafter designated P9344), BSR101, and Asgrow HIG3071 (hereafter designated A3071). P9344 and A3071 are tolerant to glyphosate, and BSR101 is susceptible to this herbicide. A3071, an experimental line, is resistant to sudden death syndrome, and cultivars BSR101 and P9344 are susceptible (38).

Field experiments. Experiments were conducted in 1997, 1998, and 1999 to assess the effect of herbicides on sudden death syndrome. Cultivars planted and herbicides used in each year are shown in Table 1. Plots were planted on 16 May 1997, 12 May 1998, and 10 May 1999. All herbicides were applied at 41 days after planting in 1997, at 45 days in 1998, and at 39 days in 1999 when soybean plants were at the V3 to V5 growth stage (11). Application of herbicides was made using a Solo Backpack sprayer system in 1997, and a $\mathrm{CO}_{2}$-powered two-man spray boom $(3 \mathrm{~m}$ long) with six nozzles (R \& D Spray System, Opelousas, LA) in 1998 and 1999. Plots were maintained weed-free by regular hoeing prior to and after herbicide application in order to minimize competition from weeds. In all 3 years, the experimental design used was a randomized complete block design with three replications and a factorial arrangement of treatments in a strip-plot $(13,41)$. Cultivars were assigned to horizontal strips and herbicides to vertical strips. Plots were $4 \mathrm{~m}$ long in 1997 and $5 \mathrm{~m}$ long in 1998 and 1999, and 4 rows 
wide with a between-row spacing of $1 \mathrm{~m}$. In 1997, plots were established in a farmer's field with history of sudden death syndrome in Scott County, IA. In 1998 and
1999, the experiment was conducted at Hinds Research Farm of Iowa State University, near Ames, in fields artificially infested with oat kernels colonized by $F$.

Table 1. Soybean cultivars and herbicides used in field experiments in 1997, 1998, and 1999

\begin{tabular}{|c|c|c|}
\hline $\begin{array}{l}\text { Year (location) } \\
\text { Cultivars }^{\mathrm{y}}\end{array}$ & Common name of herbicides & $\begin{array}{l}\text { Herbicide concentration } \\
\text { (kg a.i./ha) }\end{array}$ \\
\hline \multicolumn{3}{|c|}{1997 (Scott County, IA) } \\
\hline BSR101 & Acifluorfen & 0.41 \\
\hline \multirow[t]{3}{*}{ P9344 } & Control &.$^{z}$ \\
\hline & Glyphosate & 0.84 \\
\hline & Lactofen & 0.22 \\
\hline \multicolumn{3}{|c|}{1998 and 1999 (Story County, IA) } \\
\hline & Acifluorfen & 0.41 \\
\hline BSR101 & Control & \\
\hline P9344 & Glyphosate & 0.84 \\
\hline \multirow[t]{2}{*}{ A3071 } & Imazethapyr & 0.071 \\
\hline & Lactofen & 0.22 \\
\hline
\end{tabular}

y Cultivars P9344 and A3071 are tolerant to glyphosate, and BSR101 is not tolerant to this herbicide. A3071 is resistant to sudden death syndrome, and cultivars BSR101 and P9344 are susceptible.

${ }^{\mathrm{z}}$ Not applicable.

solani f. sp. glycines. Preparation of the oat kernel inoculum was performed according to procedures outlined by others $(39,44)$. Briefly, oats kernels were soaked for $24 \mathrm{~h}$, autoclaved twice for $1 \mathrm{~h}$, and inoculated with agar plugs of $F$. solani grown on onethird strength potato dextrose agar medium. Five $1-\mathrm{cm}$ plugs were used per $200 \mathrm{~g}$ of soaked oat kernels. The inoculated kernels were incubated at $25^{\circ} \mathrm{C}$ in the dark for 3 to 4 weeks. Infested oat kernels were spread in the seed furrow over soybean seeds at the rate of $25 \mathrm{~cm}^{3}$ per meter of row. This rate did not affect soybean stand and generated disease epidemics comparable to those found in soybean grown in naturally infested fields.

Assessment of plant health. The effect of herbicides on plant health was assessed on the basis of the following variables: (i) visual ratings of foliar disease severity, (ii) frequency of isolation of $F$. solani f. sp.
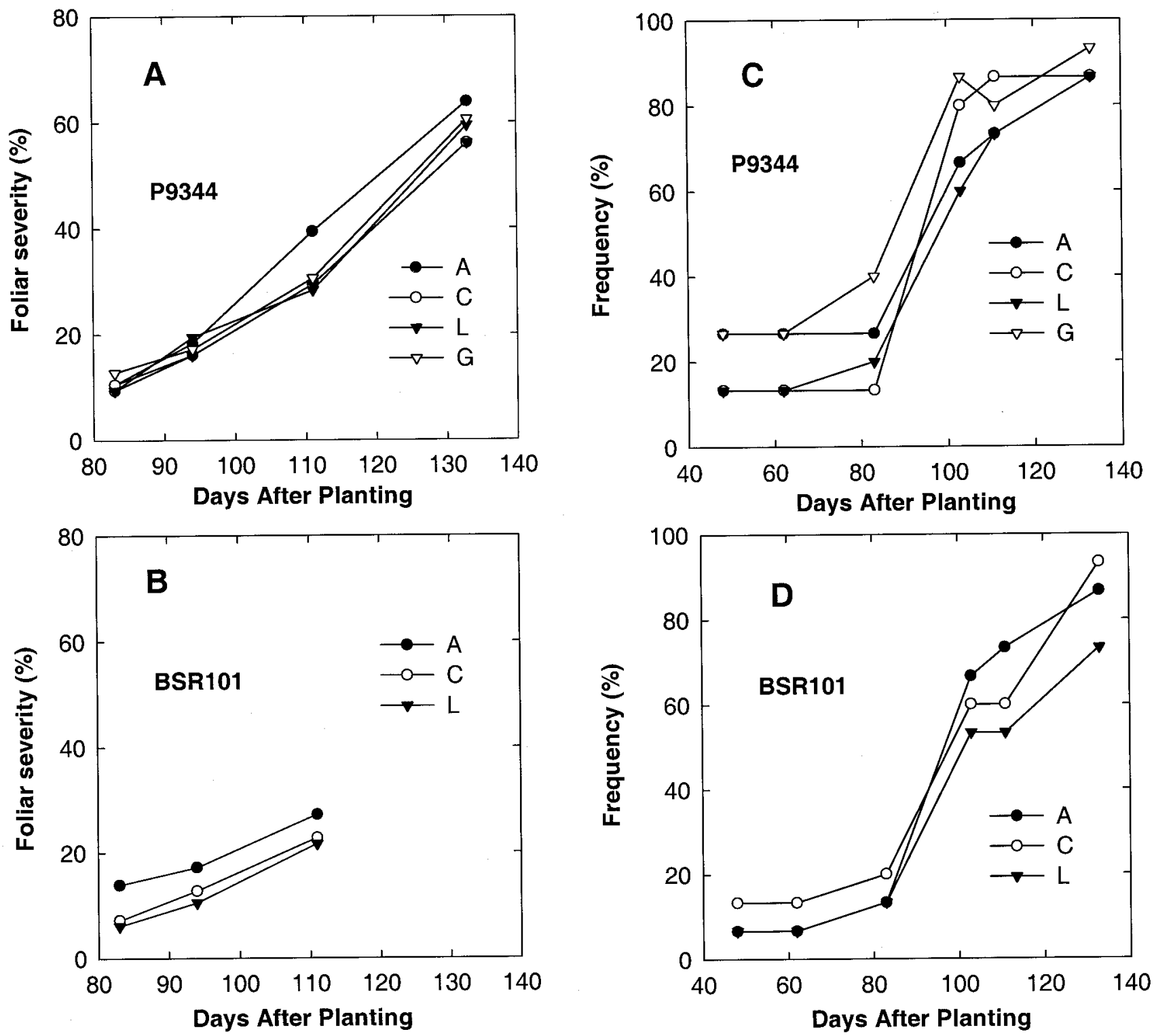

Fig. 1. Foliar severity of sudden death syndrome (A and B) and frequency of isolation of Fusarium solani f. sp. glycines from roots (C and D) of two soybean cultivars tolerant (P9344) and nontolerant (BSR101) to glyphosate during 1997 growing season. A = acifluorfen, $\mathrm{C}=$ control, $\mathrm{G}=$ glyphosate, and $\mathrm{L}=$ lactofen. 
glycines from roots, (iii) aboveground plant dry weights, and (iv) seed yield. Foliar severity of sudden death syndrome was visually evaluated from soybean growth stages R2 to R6 as average percentage of leaf area in the center two rows of each plot exhibiting sudden death syndrome symptoms using the following scale: $0=$ no foliage affected, $1=1$ to $10 \%$ (midpoint $=5 \%), 2=11$ to $20 \%$ (midpoint $=15 \%), 3=21$ to $30 \%$ (midpoint $=25 \%$ ), $50 \%$ (midpoint $=45 \%$ ), $6=51$ to $60 \%$ $($ midpoint $=55 \%), 7=61$ to $70 \%$ (midpoint $=65 \%), 8=71$ to $80 \%$ (midpoint $=$ $75 \%), 9=81$ to $90 \%$ (midpoint $=85 \%$ ), and $10=91$ to $100 \%$ (midpoint $=95 \%$ ).

To characterize root colonization by $F$. solani f. sp. glycines, five plants were arbitrarily dug from 1-m sections at each end of the two inner rows in each treatment every 2 to 3 weeks from V4-V6 to R4-R6 soybean growth stages. Plant roots were washed free from soil, and three to four 1$\mathrm{cm}$ pieces were removed from the taproot of each plant (36). These $1-\mathrm{cm}$ root pieces were agitated in $1 \%$ tergitol $\left(\mathrm{C}_{15} \mathrm{H}_{24} \mathrm{O}-\right.$ $4=31$ to $40 \%$ (midpoint $=35 \%$ ), $5=41$ to

$\mathrm{C}_{2} \mathrm{H}_{4} \mathrm{O}$ ) solution for $2 \mathrm{~min}$, surfacesterilized for $4 \mathrm{~min}$ in a $1: 1(\mathrm{vol} / \mathrm{vol}) \mathrm{mix}-$ ture of $95 \%$ ethyl alcohol $\left(\mathrm{C}_{2} \mathrm{H}_{5} \mathrm{OH}\right)$ and $0.5 \%$ sodium hypochlorite $(\mathrm{NaOCl})$ solution, rinsed in sterile distilled water, and embedded in Nash-Snyder medium (31) contained in $9-\mathrm{cm}$ plastic petri dishes. The dishes were sealed with Parafilm and incubated at room temperature $\left(22\right.$ to $24^{\circ} \mathrm{C}$ ) for 14 days, and the number of root segments yielding $F$. solani f. sp. glycines was recorded for each treatment.

To assess soybean plant growth in each treatment, each plot was sampled at 1, 3, and 6 weeks after herbicide application in 1997, at 1, 3, 5, and 7 weeks in 1998, and at 1, 3, 5, and 9 weeks in 1999. These various sampling periods covered soybean growth stages from V4-V6 to R1-R2 in 1997, and from V4-V6 to R3-R4 in 1998 and 1999. At each sampling period, shoots from five plants were arbitrarily harvested from each treatment plot, placed in an oven at $60^{\circ} \mathrm{C}$, and dry weights were recorded after $48 \mathrm{~h}$. Seed yield was assessed on a 2-m section from the center of the two inner rows of each

Table 2. Observed significance levels $(P)$ of $F$ tests for the effects of soybean cultivar, herbicide, and cultivar-herbicide interaction on plant health variables measured in 1997, 1998, and 1999

\begin{tabular}{|c|c|c|c|c|}
\hline \multirow{2}{*}{$\begin{array}{l}\text { Year } \\
\text { Source of variation }\end{array}$} & \multicolumn{4}{|c|}{ Plant health variables } \\
\hline & AUDPC $^{\mathbf{y}}$ & AURIC' & Shoot dry weight $^{z}$ & Yield (kg/ha) \\
\hline \multicolumn{5}{|l|}{1997} \\
\hline Cultivar & 0.004 & 0.230 & 0.900 & 0.442 \\
\hline Herbicide & 0.010 & 0.304 & 0.711 & 0.996 \\
\hline Cultivar-herbicide & 0.605 & 0.900 & 0.572 & 0.617 \\
\hline \multicolumn{5}{|l|}{1998} \\
\hline Cultivar & 0.0004 & 0.041 & 0.305 & 0.800 \\
\hline Herbicide & 0.370 & 0.100 & 0.105 & 0.334 \\
\hline Cultivar-herbicide & 0.387 & 0.477 & 0.182 & 0.750 \\
\hline \multicolumn{5}{|l|}{1999} \\
\hline Cultivar & 0.0001 & 0.0003 & 0.718 & 0.148 \\
\hline Herbicide & 0.017 & 0.001 & 0.033 & 0.360 \\
\hline Cultivar-herbicide & 0.592 & 0.457 & 0.270 & 0.133 \\
\hline
\end{tabular}

y AUDPC $=$ area under the disease progress curve, derived from visual ratings of foliar severity of sudden death syndrome; and AURIC = area under the root infection curve, derived from the frequency of isolation of Fusarium solani f. sp. glycines from roots.

${ }^{\mathrm{z}}$ Data were subjected to $\log$ (base e) transformation before analysis. plot. Yield was adjusted to $13 \%$ moisture content.

Data analysis. In this study, the data sets subjected to statistical analysis comprised the following variables: (i) the area under disease progress curve (AUDPC) derived from visual ratings of foliar disease severity using the midpoint values, (ii) the area under the root infection curve (AURIC) derived from the frequency of isolation of $F$. solani f. sp. glycines from roots, (iii) the aboveground plant dry weights from all sampling periods, and (iv) seed yield. The effects of cultivar and herbicide on these variables were tested for significance by analysis of variance (ANOVA) for a strip-plot design as outlined by Gomez and Gomez (13). The analysis was performed separately for each of the 3 years of the experiment. Fisher's protected least significant difference test was used at the $5 \%$ significance level to separate treatment means.

\section{RESULTS}

Plant health in 1997 experiment. In 1997 , foliar severity of sudden death syndrome was assessed on 7 and 18 August and 4 September for cultivars P9344 and BSR101; a fourth assessment was made for cultivar P9344 on 26 September (Fig. 1A and B). Due to leaf-fall, no fourth assessment was made for BSR101. Disease intensities were compared for the periods when assessments were available for both cultivars. Analysis of variance conducted on the area under disease progress curve (AUDPC) indicated that there was no significant cultivar-herbicide interaction $(P=$ 0.605; Table 2). However, there was a significant difference in mean AUDPC among herbicide treatments $(P=0.010$; Table 2) and cultivars $(P=0.004$; Table 2$)$. Except for lactofen, all herbicides increased disease severity compared with the control treatment (Table 3). Figure 1C and D display the frequency of isolation of $F$. solani $\mathrm{f}$. sp. glycines from roots of soybean

Table 3. Means for plant health variables for which significant cultivar and herbicide effects were detected in 1997, 1998, and 1999w

\begin{tabular}{|c|c|c|c|c|c|c|}
\hline & \multicolumn{2}{|c|}{1997} & \multicolumn{2}{|c|}{1998} & \multicolumn{2}{|c|}{1999} \\
\hline & AUDPC $^{x}$ & AURIC $^{x}$ & AUDPC & AURIC & AUDPC & AURIC \\
\hline Cultivar & & $\mathrm{NS}^{\mathrm{y}}$ & & & & \\
\hline P9344 & $571 \mathrm{a}$ & & $926 \mathrm{a}$ & $2,590 \mathrm{a}$ & $811 \mathrm{a}$ & $4,432 \mathrm{a}$ \\
\hline BSR101 & $442 \mathrm{~b}$ & & $320 \mathrm{~b}$ & $2,490 \mathrm{a}$ & $428 \mathrm{~b}$ & $4,513 \mathrm{a}$ \\
\hline A3071 & $\ldots^{\mathrm{z}}$ & & $106 \mathrm{c}$ & $1,674 \mathrm{~b}$ & $72 \mathrm{c}$ & $2,016 \mathrm{~b}$ \\
\hline Herbicide & & NS & NS & NS & & \\
\hline Acifluorfen & $600 \mathrm{a}$ & & & & $450 \mathrm{a}$ & $3,896 \mathrm{a}$ \\
\hline Control & $473 \mathrm{~b}$ & & & & $430 \mathrm{bc}$ & $3,407 \mathrm{bc}$ \\
\hline Glyphosate & $571 \mathrm{a}$ & & & & $469 \mathrm{a}$ & $3,563 \mathrm{ab}$ \\
\hline Imazethapyr & $\ldots$ & & & & $441 \mathrm{ab}$ & $3,811 \mathrm{a}$ \\
\hline Lactofen & $447 \mathrm{~b}$ & & & & $407 \mathrm{c}$ & $3,274 \mathrm{c}$ \\
\hline
\end{tabular}

${ }^{\text {w}}$ For each effect (cultivar or herbicide), numbers within a column followed by the same letters are not significant at $P=0.05$. Cultivars P9344 and A3071 are tolerant to glyphosate, and BSR101 is not tolerant to this herbicide. A3071 is resistant to sudden death syndrome, and cultivars BSR101 and P9344 are susceptible.

$\times$ AUDPC $=$ area under the disease progress curve, derived from visual ratings of foliar severity of sudden death syndrome; and AURIC $=$ area under the root infection curve, derived from the frequency of isolation of Fusarium solani f. sp. glycines from roots.

y Not significant.

${ }^{\mathrm{z}}$ Treatment not available. 
plants at various periods in the growing season in 1997. Analysis of variance conducted on the area under the root infection curve (Table 2) indicated that there was no significant cultivar-herbicide interaction $(P=0.900)$. Similarly, there was no significant difference in the area under the infection curve among herbicide treatments $(P=0.304)$ and cultivars $(P=0.230)$. As gauged by aboveground plant dry weight (Table 2), soybean growth was not significantly affected by cultivar $(P=0.900)$, herbicide $(P=0.711)$, and their interaction $(P=0.572)$. Similarly, seed yield (Table 2$)$ was not significantly affected by cultivar $(P=0.442)$, herbicide $(P=0.996)$, and their interaction $(P=0.617)$.

Plant health in 1998 experiment. Foliar severity of sudden death syndrome was recorded at four periods in 1998. As revealed in the disease progress curve (Fig. $2 \mathrm{~A}$ to $\mathrm{C}$ ), disease severity was higher in cultivars P9344 and BSR101 than in A3071. Analysis of variance for the area under the disease progress curves (Tables 2 and 3) indicated that there was no significant cultivar-herbicide interaction $(P=$ 0.387). Differences among herbicide treatments were not statistically significant $(P=0.370)$. Cultivar was the factor that exerted the most significant effect on disease severity $(P=0.0004)$ integrated over all assessment periods.

Figure $2 \mathrm{D}$ to $\mathrm{F}$ depicts the frequency of isolation of $F$. solani $\mathrm{f}$. sp. glycines from roots of soybean plants at various periods in the growing season in 1998. Analysis of variance conducted on the area under the root infection curve (Tables 2 and 3) indicated that there was no significant cultivar-herbicide interaction $(P=0.477)$. Similarly, there was no significant difference in the area under the root infection curve among herbicide treatments $(P=$ $0.100)$. However, there was a significant difference in the area under the infection curve among cultivars $(P=0.041)$. As gauged by aboveground plant dry weight (Table 2), soybean growth was not significantly affected by cultivar $(P=0.305)$, herbicide $(P=0.105)$, and their interaction $(P=0.182)$. Similarly, seed yield (Table 2$)$ was not significantly affected by cultivar $(P=0.800)$, herbicide $(P=0.334)$, and their interaction $(P=0.750)$.

Plant health in 1999 experiment. Foliar severity of sudden death syndrome was recorded at five periods in 1999. As revealed in the disease progress curves (Fig. 3A to C), disease severity was higher in cultivars P9344 and BSR101 than in A3071. Analysis of variance for the area under the disease progress curve (Tables 2 and 3) indicated that there was no significant cultivar-herbicide interaction $(P=$ 0.592). However, there were statistically significant effects of herbicide $(P=0.017)$ and cultivar $(P=0.0001)$ on disease severity integrated over all assessment dates.

Figure $3 \mathrm{D}$ to $\mathrm{F}$ shows the frequency of isolation of $F$. solani f. sp. glycines from roots of soybean plants at various periods in the growing season in 1999. Analysis of variance conducted on the area under the root infection curve (Tables 2 and 3) indicated that there was no significant cultivar-herbicide interaction $(P=0.457)$. However, the area under the root infection curve was significantly affected by herbicide treatment $(P=0.001)$ and cultivar $(P$ $=0.0003)$. Aboveground plant dry weight (Table 2) was significantly affected by herbicide treatment $(P=0.033)$. Seed yield (Table 2) was not significantly affected by cultivar $(P=0.148)$, herbicide $(P=0.360)$, and their interaction $(P=0.133)$.

\section{DISCUSSION}

The scope of this study was defined by the speculation on the susceptibility of glyphosate-tolerant soybean cultivars to sudden death syndrome. The main conclusions were the following: (i) the response of glyphosate-tolerant and conventional soybeans to infection by $F$. solani f. sp. glycines was similar under application of herbicides; (ii) there was an increase in severity of sudden death syndrome in plants treated with acifluorfen, glyphosate, and imazethapyr compared with nontreated or lactofen-treated plants; and (iii) the resistance of soybean to sudden death syndrome was not changed with application of glyphosate. These conclusions are in agreement with those from greenhouse and growth chamber studies (38). Lee et al. (26) reported similar results, indicating that the glyphosate resistance trait and the application of glyphosate did not influence the susceptibility of soybean to Sclerotinia sclerotiorum in the greenhouse.

$F$. solani is a ubiquitous fungal organism that is capable of inflicting serious damage to many crops, especially in the presence of crop stress, which may arise from fluctuations in physical and chemical environments $(4,15)$. Crop stress originating from application of herbicides is manifested by various physiological and morphological changes in plants $(4,15)$. The herbicides used in this work represent two chemical families, one involved in the disruption of cell membranes (acifluorfen and lactofen) and the other in the inhibition of enzyme activity in the synthesis of certain amino acids (imazethapyr and glyphosate). Except for lactofen, no severe leaf injury was apparent in plants sprayed with herbicides. Although lactofen was found to decrease aboveground plant dry weight and leaf chlorophyll content (data not shown) within 4 to 10 days after application, complete vegetative recovery was attained by the third week after application of this herbicide. Despite the transient stress observed in lactofen-treated plants, disease levels were lower in these plants compared with those treated with acifluorfen, glyphosate, and imazethapyr. Lactofen has been shown to induce plant-mediated re- sponses involved in disease suppression (7), and it is conceivable that similar responses may be produced by soybean plants affected by sudden death syndrome and treated with this herbicide. Although glyphosate has little or no direct effect on $F$. solani (23), this herbicide appears to impose some level of stress that may explain the higher level of disease in glyphosate-treated plants compared with nontreated or lactofen-treated plants. Similarly, plant stress may have also been induced in plants treated with acifluorfen and imazethapyr resulting in disease levels comparable to those in glyphosate-treated plants.

The development of sudden death syndrome is commonly monitored on the basis of visual rating of foliar symptoms (16), and occasionally root symptoms have been taken into account (14). In this study, in addition to visual rating of foliar symptoms, we used the frequency of isolation of $F$. solani f. sp. glycines from roots of soybean plants as a criterion for assessing differences among treatments. Root colonization using frequency of isolation or colony-forming units per unit weight of root tissue $(6,28,32)$, albeit tedious and time-consuming, is an important bioassay method in the detection of plant infection prior to the appearance of foliar symptoms (28). We consistently detected differences among cultivars using ratings of foliar symptoms. Conversely, based on root colonization, differences among cultivars were discernable only when a resistant cultivar was included in the study. These findings are in agreement with those by Luo et al. (28). The resistant cultivar (A3071) in this study consistently had the lowest disease intensity with regard to ratings of foliar symptoms and frequency of isolation of $F$. solani f. sp. glycines from plant roots. However, foliar resistance may not always be correlated with root resistance to fungal colonization (28).

The lack of statistically significant cultivar-herbicide interaction for foliar symptom ratings and root colonization indicates that glyphosate-tolerant and nontolerant soybeans respond similarly to sudden death syndrome under herbicide application. Statistically significant main effects of cultivars were detected consistently in all 3 years of the study for foliar disease integrated over the entire rating period in each growing season. For the same variable, the main effect of herbicide was significant in 1997 and 1999, and was nonsignificant in 1998. When the frequency of isolation from roots was integrated over the isolation period in each growing season, we detected nonsignificant effects of herbicide and cultivar in 1997, nonsignificant effect of herbicide in 1998, and significant effects of herbicide and cultivar in 1999. These variations from year to year may be ascribed to variations in environmental factors influencing the development of foliar 

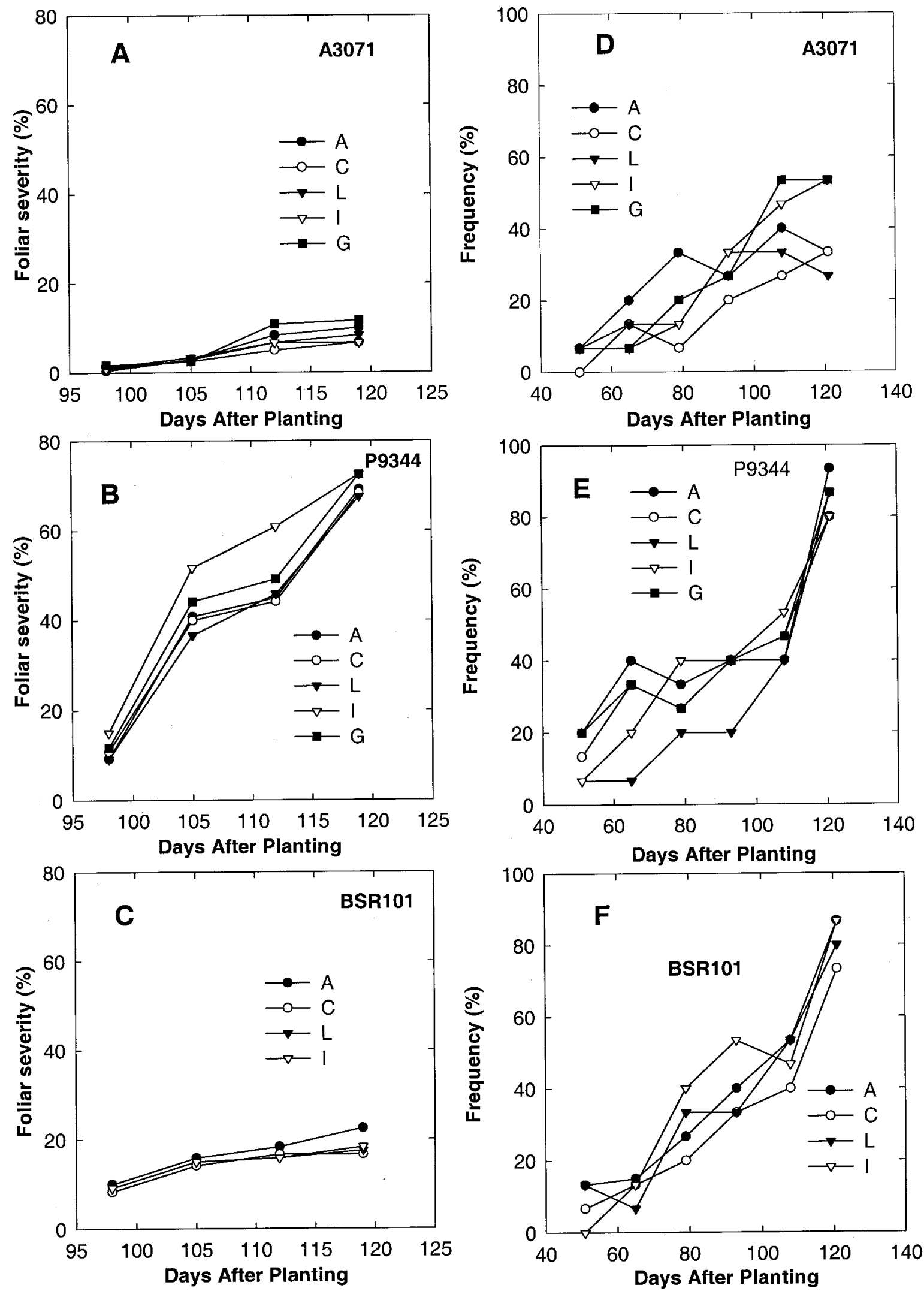

Fig. 2. Foliar severity of sudden death syndrome (A, B, and C) and frequency of isolation of Fusarium solani f. sp. glycines from roots (D, E, and F) of three soybean cultivars tolerant (A3071 and P9344) and nontolerant (BSR101) to glyphosate during 1998 growing season. A = acifluorfen, C = control, G = glyphosate, $\mathrm{I}=$ imazethapyr, and $\mathrm{L}=$ lactofen. 

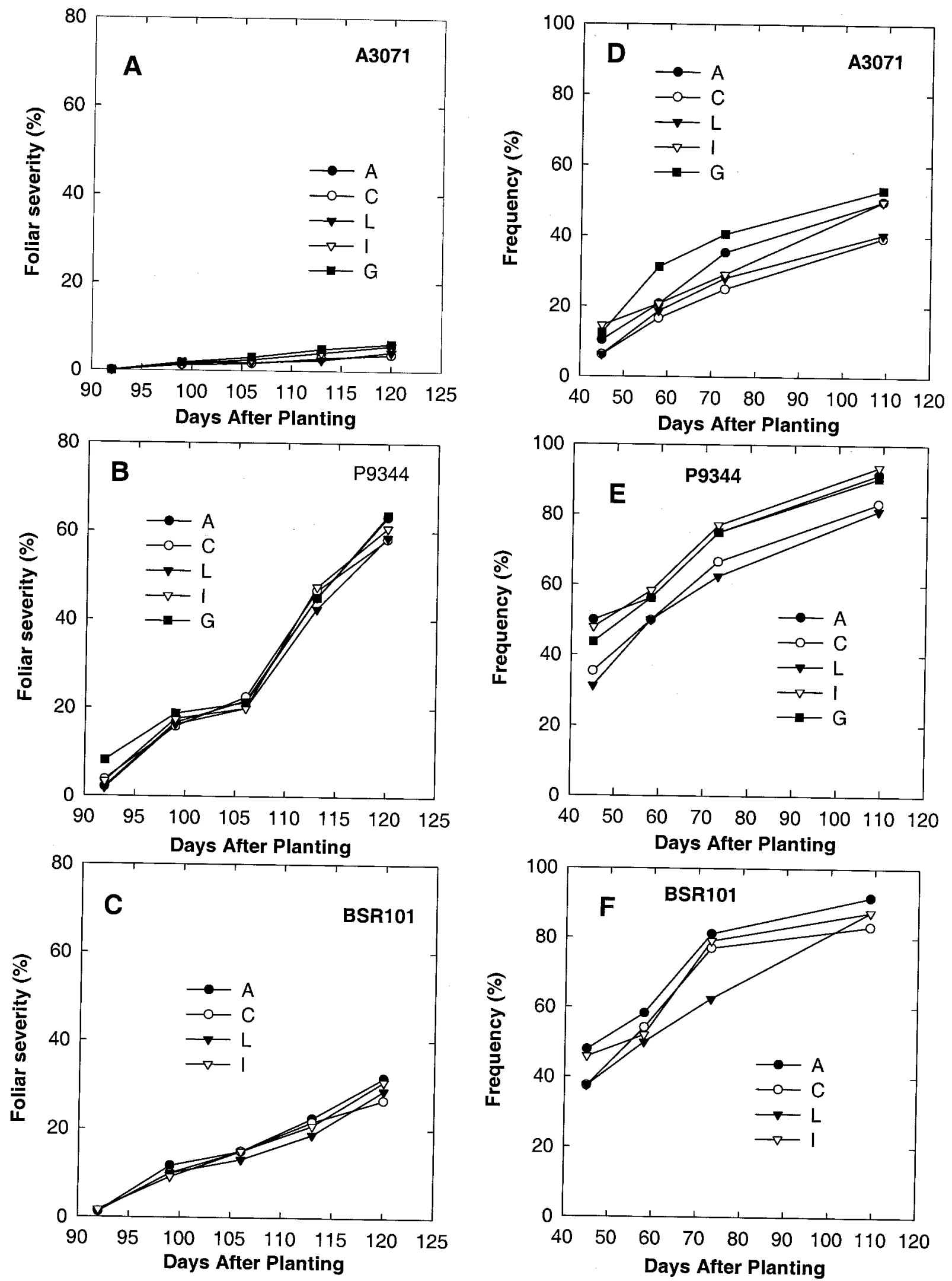

Fig. 3. Foliar severity of sudden death syndrome (A, B, and C) and frequency of isolation of Fusarium solani f. sp. glycines from roots (D, E, and F) of three soybean cultivars tolerant (A3071 and P9344) and nontolerant (BSR101) to glyphosate during 1999 growing season. A = acifluorfen, C = control, G = glyphosate, $\mathrm{I}=$ imazethapyr, and $\mathrm{L}=$ lactofen. 
symptoms and root colonization by $F$. solani f. sp. glycines $(18,37,39)$. Where herbicide effects were significant, lower disease intensity was recorded in lactofentreated or nontreated plants than in plants treated with acifluorfen, glyphosate, and imazethapyr.

This study was conducted from the assumption that only one postemergence application of glyphosate would be necessary to manage weeds. Additionally, we assumed that this herbicide would be applied during the early growth stages of the soybean plant. However, weed management schemes are variable and may include applying glyphosate during burn down, followed by one or more postemergence applications during the vegetative and reproductive stages of the soybean plant. The intensity of sudden death syndrome may need to be appraised within the context of all these activities, which may influence the level of crop stress. Further, the degree of overlapping between window of herbicide stress and window of infection, which is determined by favorable soil temperatures and moisture, may also affect the amount of disease.

\section{ACKNOWLEDGMENTS}

We thank P. Vance and A. Schiller for technical assistance. Journal Paper J-19226 of the Iowa Agriculture and Home Economics Experiment Station, Ames, Project 2869. Supported by Hatch Act and State of Iowa funds, the Iowa Soybean Promotion Board, and the North Central IPM Program.

\section{LITERATURE CITED}

1. Altman, J., and Campbell, C. L. 1977. Effect of herbicides on plant diseases. Annu. Rev. Phytopathol. 15:361-385.

2. Altman, J., and Rovira, A. D. 1989. Herbicide-pathogen interactions in soil-borne root diseases. Can. J. Plant Pathol. 11:166-172.

3. Anonymous. 1994-1999. Agricultural chemical usage survey. U.S. Dep. Agric. Natl. Agric. Stat. Serv.

4. Ayres, P. G. 1984. The interaction between environmental stress injury and biotic disease physiology. Annu. Rev. Phytopathol. 22:53-75.

5. Brammall, R. A., and Higgins, V. J. 1987. The effect of glyphosate on resistance of tomato to Fusarium crown and root rot disease and on the formation of host structural defensive barriers. Can. J. Bot. 66:1547-1555.

6. Canaday, C. H., Helsel, D. G., and Wyllie, T. D. 1986. Effects of herbicide-induced stress on root colonization of soybeans by Macrophomina phaseolina. Plant Dis. 70:863-866.

7. Dann, E. K., Diers, B. W., and Hammerschmidt, R. 1999. Suppression of Sclerotinia stem rot of soybean by lactofen herbicide treatment. Phytopathology 89:598-602.

8. Delannay, X., Bauman, T. T., Beighley, D. H., Buettner, M. J., Coble, H. D., DeFelice, M. S., Derting, C. W., Diedrick, T. J., Griffin, J. L., Hagood, E. S., Hancock, F. G., Hart, S. E., LaVallee, B. J., Loux, M. M., Lueschen, W. E., Matson, K. W., Moots, C. K., Murdock, F. G., Nickell, A. D., Owen, M. D. K., Paschal II, E. H., Prochaska, L. M., Raymond, P. J., Reynolds, D. B., Rhodes, W. K., Roeth, F. W., Sprankle, P. L., Tarochione, L. J., Tinius, C. N., Walker, R. H., Wax, L. M., Weigelt, H. D., and Padgette, S. R. 1995. Yield evaluation of a glyphosate-tolerant soybean line after treatment with glyphosate. Crop Sci. 35:1461-
1467.

9. Descalzo, R. C., Punja, Z. K., Levesque, C. A., and Rahe, J. E. 1998. Glyphosate treatment of bean seedlings causes short-term increases in Pythium populations and damping off potential in soils. Appl. Soil Ecol. 8:25-33.

10. Duke, S. O., ed. 1996. Herbicide-Resistant Crops: Agricultural, Environmental, Economic, Regulatory, and Technical Aspects. Lewis Publishers, Boca Raton, FL.

11. Fehr, W. R., Caviness, C. E., Burmood, D. T., and Pennington, J. S. 1971. Stage of development descriptions for soybeans, Glycine $\max ($ L.) Merrill. Crop Sci. 11:929-931.

12. Gasser, C. 1989. Genetically engineering plants for crop improvement. Science 244:1293-1299.

13. Gomez, K. A., and Gomez, A. A. 1983. Statistical Procedures for Agricultural Research. John Wiley \& Sons, New York.

14. Gray, L. E., and Achenbach, L. A. 1996. Severity of foliar symptoms and root and crown rot of soybean inoculated with various isolates and inoculum rates of Fusarium solani. Plant Dis. 80:1197-1199.

15. Griffiths, E. 1981. Iatrogenic plant diseases. Annu. Rev. Phytopathol. 19:69-82.

16. Hartman, G. L., Huang, Y. H., Nelson, R. L., and Noel, G. R. 1997. Germplasm evaluation of Glycine max for resistance to Fusarium solani, the causal organism of sudden death syndrome. Plant Dis. 81:515-518.

17. Hartzer, R., Wintersteen, W., and Pringnitz, B. 1997. A survey of pesticides used in Iowa crop production in 1995. Iowa State University Ext. Pamphl. Pm-1718.

18. Hershman, D. E., Hendrix, J. W., Stuckey, R. E., Bachi, P. R., and Henson, G. 1990. Influence of planting date and cultivar on soybean sudden death syndrome in Kentucky. Plant Dis. 74:761-766.

19. Holliday, M. J., and Keen, N. T. 1982. The role of phytoalexins in the resistance of soybean leaves to bacteria: Effects of glyphosate on glyceollin accumulation. Phytopathology 72:1470-1474.

20. Holzman, D. 1999. Agricultural Biotechnology. Genet. Eng. News 19:1,12,39.

21. Johal, G. S., and Rahe, J. E. 1984. Effect of soilborne plant pathogenic fungi on the herbicidal action of glyphosate on bean seedlings. Phytopathology 74:950-955.

22. Johal, G. S., and Rahe, J. E. 1990. Role of phytoalexins in the suppression of resistance of Phaseolus vulgaris to Colletotrichum lindemuthianum by glyphosate. Can. J. Plant Pathol. 12:225-235.

23. Kawate, M. K., Kawate, S. C., Ogg, A. G., Jr., and Kraft, J. M. 1992. Response of Fusarium solani f. sp. pisi and Pythium ultimum to glyphosate. Weed Sci. 40:497-502.

24. Keen, N. T., Holliday, M. J., and Yoshikawa, M. 1982. Effects of glyphosate on glyceollin production and the expression of resistance to Phytophthora megasperma f. sp. glycinea in soybean. Phytopathology 72:1467-1470.

25. Latunde-Dada, A. O., and Lucas, J. A. 1985. Involvement of the phytoalexin medicarpin in the differential response of callus lines of lucerne (Medicago sativa) to infection by Verticillium albo-atrum. Physiol. Plant Pathol. 26:31-42.

26. Lee, C. D., Penner, D., and Hammerschmidt, R. 2000. Influence of formulated glyphosate and activator adjuvants on Sclerotinia sclerotiorum in glyphosate-resistant and -susceptible Glycine max. Weed Sci. 48:710-715.

27. Lévesque, C. A., Rahe, J. E., and Eaves, D. M. 1987. Effects of glyphosate on Fusarium spp.: Its influence on root colonization of weeds, propagule density in the soil, and crop emergence. Can. J. Microbiol. 33:354-360.

28. Luo, Y., Myers, O., Lightfoot, D. A., and
Schmidt, M. E. 1999. Root colonization of soybean cultivars in the field by Fusarium solani f. sp. glycines. Plant Dis. 83:1155-1159.

29. Lynch, J. M., and Penn, D. J. 1980. Damage to cereals caused by decaying weed residues. J. Sci. Food Agric. 31:321-324.

30. Moesta, P., and Grisebach, H. 1982. L-2aminooxy-3-phenylpropionic acid inhibits phytoalexin accumulation in soybean with concomitant loss of resistance against Phytophthora megasperma f. sp. glycinea. Physiol. Plant Pathol. 21:65-70.

31. Nash, S. M., and Snyder, W. C. 1962. Quantitative estimation by plate counts of propagules of the bean root rot Fusarium in field soils. Phytopathology 52:567-572.

32. Njiti, V. N., Suttner, R. J., Gray, L. E., Gibson, P. T., and Lightfoot, D. A. 1997. Ratereducing resistance to Fusarium solani $\mathrm{f}$. sp. phaseoli underlies field resistance to soybean sudden death syndrome. Crop Sci. 37:132138.

33. Padgette, S. R., Kolacz, K. H., Delannay, X. Re, D. B., LaVallee, B. J., Tinius, C. N., Rhodes, W. K., Otero, Y. I., Barry, G. F., Eichholtz, D. A., Peschke, V. M., Nida, D. L., Taylor, N. B., and Kishore, G. M. 1995 Development, identification, and characterization of a glyphosate-tolerant soybean line. Crop Sci. 35:1451-1461.

34. Roy, K. W. 1997. Fusarium solani on soybean roots: Nomenclature of the causal agent of sudden death syndrome and identity and relevance of $F$. solani form B. Plant Dis. 81:259 266.

35. Roy, K. W., Rupe, J. C., Hershman, D. E., and Abney, T. S. 1997. Sudden death syndrome of soybean. Plant Dis. 81:1100-1111.

36. Rupe, J. C. 1989. Frequency and pathogenicity of Fusarium solani recovered from soybeans with sudden death syndrome. Plant Dis. 73:581-584.

37. Rupe, J. C., Gbur, E. E., and Marx, D. M. 1991. Cultivar responses to sudden death syndrome. Plant Dis. 75:47-50.

38. Sanogo, S., Yang, X. B., and Scherm, H. 2000. Effects of herbicides on Fusarium solani f. sp. glycines and development of sudden death syndrome in glyphosate-tolerant soybean. Phytopathology 90:57-66.

39. Scherm, H., and Yang, X. B. 1996. Development of sudden death syndrome of soybean in relation to soil temperature and soil water matric potential. Phytopathology 86:642-649.

40. Sharon, A., Amsellem, Z., and Gressel, J. 1992. Glyphosate suppression of induced defense responses: Increased susceptibility of Cassia obtusifolia to a mycoherbicide. Plant Physiol. 98:654-659.

41. Simpson, D. M., and Stoller, E. W. 1995. Response of sulfonylurea-tolerant soybean (Glycine max) and selected weed species to imazethapyr and thifensulfuron combinations. Weed Technol. 9:582-586.

42. Smiley, R. W., Ogg, A. G., Jr., and Cook, R. J. 1992. Influence of glyphosate on Rhizoctonia root rot, growth, and yield of barley. Plant Dis. 76:937-942.

43. Starratt, A. N., and Lazarovits, G. 1996. Increase in free amino acid levels in tomato plants accompanying herbicide-induced disease resistance. Pestic. Biochem. Physiol. 54:230-240.

44. Stephens, P. A., Nickell, C. D., Moots, C. K., and Lim, S. M. 1993. Relationship between field and greenhouse reactions of soybean to Fusarium solani. Plant Dis. 77:163-166.

45. Ward, E. W. B. 1984. Suppression of metalaxyl activity by glyphosate: Evidence that host defense mechanisms contribute to metalaxyl inhibition of Phytophthora megasperma f. sp. glycinea in soybeans. Physiol. Plant Pathol. 25:381-386. 